\title{
Reef Fish Status in Northern Acehnese Reef Based on Management Type
}

\author{
EDI RUDI ${ }^{1, \vartheta}$, SAYYID AFDHAL ELRAHIMI ${ }^{1}$, TASRIF KARTAWIJAYA ${ }^{2}$, YUDI HERDIANA ${ }^{2}$, \\ FAKHRIZAL SETIAWAN ${ }^{2}$, SHINTA T. PARDEDE ${ }^{2}$, STUART J. CAMPBELL ${ }^{2}$, JERKER TAMELANDER ${ }^{3}$ \\ ${ }^{1}$ Faculty of Science, Syiah Kuala University (UNSYIAH), Banda Aceh 23111 \\ ${ }^{2}$ Wildlife Conservation Society (WCS) Indonesian Program, Bogor 16151 \\ ${ }^{3}$ IUCN, Coastal Oceans Research and Development-Indian Ocean (IUCN-CORDIO), Rue Mauverney 28, CH 1196
}

Received: $12^{\text {th }}$ December 2008. Accepted: $23^{\text {rd }}$ February 2008.

\begin{abstract}
The objectives of this study were to provide reliable data and information on reef fish in the northern Aceh region of Weh and Aceh islands based on management types. This research use underwater visual census techniques at 29 sites around Weh Island and Aceh Islands. Reef fish abundance in area that were protected under the management of Panglima Laot of Sabang Weh Island (32505 no.ha $\left.{ }^{-1}\right)$ and biomass $\left(748 \mathrm{~kg} \cdot \mathrm{ha}^{-1}\right)$ were also significantly higher than in Aceh Islands which is open access areas (abundance $=9539$ no.ha ${ }^{-1}$; biomass $=396 \mathrm{~kg} \cdot \mathrm{ha}^{-1}$ ). Fish species from the family Pomacentridae (damsel fish) were highest in abundance and biomass at northern Acehnese reef. Population of carnivorous fish such as parrotfish (Family Scaridae) was low in all study sites which indicated that northern Acehnese reef is lack of reef resilience both in managed and open access area. Higher numbers and abundance of reef fish in marine managed areas, such as Panglima Laot in Sabang, could be considered for further conservation purpose of marine resources.
\end{abstract}

(C) 2009 Biodiversitas, Journal of Biological Diversity

Key words: Coral reef, reef fish, management type, northern Acehnese reef

\section{INTRODUCTION}

The reefs at northern Acehnese are dominated by massive species (mainly Poritidae and Faviidae) intermingled by patches of branching Acropora and Montipora species in sheltered areas and mostly branching species at high-energy reefs (Brown, 2005). Weh Island and Aceh Islands are the two main islands in northern Aceh and also the western most reef areas in the Indonesian archipelago. The marine fauna and flora of north-west Sumatra, including the northern Aceh reefs are comprised of species from the Indian Ocean and the Pacific Ocean and make the region biogeographically distinct from eastern Indonesian coral reef species.

Coral reefs of Weh Island are known to be generally in better condition than those on Aceh islands because of past differences in management between these two regions of northern Aceh. The reefs are important for fisheries with a range of artisenal gears used and mainly pelagic commercial fisheries. The area is known for its tourism industry

\footnotetext{
- Correspnding address:

Kampus Unsyiah, Darussalam, Banda Aceh 23111

Tel. \& Fax.: +62-651-7428212; +62-651-7410248

e-mail: edirudi@yahoo.com
}

with snorkeling and SCUBA diving and other recreational activities as the main attractions. These activities contribute income to coastal communities, in addition to farming, business, and government sectors (Baird et al., 2005).

Coral reefs habitats and their associated fauna and flora are therefore important marine ecosystems with important ecological functions and services in the region. Although these reefs were subject to substantial disturbance from the tsunami, initial claims that northern Aceh reefs were destroyed or greatly impacted by the tsunami in 2004 were unfounded (Brown, 2005). Nevertheless damage to coastal communities was severe with five of thirteen villages in Weh Island heavily affected by the earthquake and tsunami; mostly the northern and southern coasts. Damaged houses, boats, fishing gears, and loss of life paralyzed the economic state of northern Aceh's fisheries, including the destructive fishing activities. However, overfishing and destructive fishing practices had caused serious damage and significantly degraded coral reef ecosystems in Aceh Islands prior to the tsunami (Baird et al., 2005).

The reefs of Northern Aceh range from those are very poor to those in good condition but generally have only been recently well documented (Baird et al., 2005; Campbell et al., 2005a,b; Rudi, 2005; Ardiwijaya et al., 2007). To improve the management 
of these reefs and prevent damaging, unsustainable, and illegal fishing practices from returning, investment is required to implement management practices and strategies that help rehabilitate, restore and protect marine resources through programs of regular monitoring, education, coastal management and establishment and maintenance of marine protected areas. Wantiez et al. (1997) and Aswani et al. (2007) concluded that species richness, density and biomass of fish on the protected reefs were higher and statistically significant compare with open access reef.

Indonesia possesses the world's richest reef fish fauna. Stretching in an east-west direction for approximately $5,000 \mathrm{~km}$ and embracing nearly 18,000 islands, the archipelago features a seemingly endless array of marine habitats. Although universally acclaimed as the leading reef fish locality, there is no comprehensive, published faunal list to substantiate this assertion. Randall (1998) proposed several key factors for the proliferation of coral reef species in the East Indian region, i.e. Weh Island and surrounding areas. Study of Allen and Adrim (2003) indicates that 6 species of reef fishes are currently considered Acehnese endemics.

The aim of this research was to provide reliable data and information on coral reef resources of northern Aceh especially reef fish based on management type. Hopeful, the results would be useful for local people, scientists, tourists, and other stakeholders to evaluate the reef fish status and be used to evaluate the effectiveness of future marine resources management.

\section{MATERIAL AND METHODS}

Coral reef surveys was conducted at 21 sites; consisting of 13 sites on Weh Island and 8 sites on Aceh Islands. Coral reef fish surveys were conducted at 29 sites; consisting of 19 sites on Weh Island and 10 sites on Aceh Islands (Figure 1). Sites were selected to represent the reefs of the region and the types of site management including: Marine Protected Area (MPA, consisted of Panglima Laot and Tourism Reserve) where fishing restrictions are in place and unrestricted fishing or open access areas.

The method used in this research was underwater visual census technique (VCT) for reef fishes (English et al., 1997; Hill and Wilkinson, 2004). In order to obtain representative data of the reef, transects were laid at two waters depths at 2-3 m (shallow) and 6-8 $\mathrm{m}$ (deep). Data were collected at the species level and 9 size classes visually estimated $(0 \mathrm{~cm}, 5-10 \mathrm{~cm}$, $10-15 \mathrm{~cm}, 15-20 \mathrm{~cm}, 20-25 \mathrm{~cm}, 25-30 \mathrm{~cm}, 30-35 \mathrm{~cm}$, $35-40 \mathrm{~cm}$ and $>40 \mathrm{~cm}$ ) along 3 replicate $5 \times 50 \mathrm{~m}^{2}$ belttransects for fish $>10 \mathrm{~cm}$ and 3 replicate $2 \times 50 \mathrm{~m} 2$ area for fish $<10 \mathrm{~cm}$. Data was converted to number of individuals per hectare (no.ha ${ }^{-1}$ ) (fish abundance) and also kilograms per hectare $\left(\mathrm{kg}^{-\mathrm{ha}^{-1}}\right.$ ) (fish biomass) using length-weight relationships for fish species using the following equation:

$$
\begin{aligned}
& \mathbf{W}=\mathbf{a} \mathbf{L}^{\mathbf{b}} \\
& \mathbf{W}=\text { weight }(\mathrm{kg}) \\
& a \text { and } \mathbf{b}=\text { constant (taken from Fish Base, 2000) } \\
& L=\text { length }(\mathrm{cm})
\end{aligned}
$$

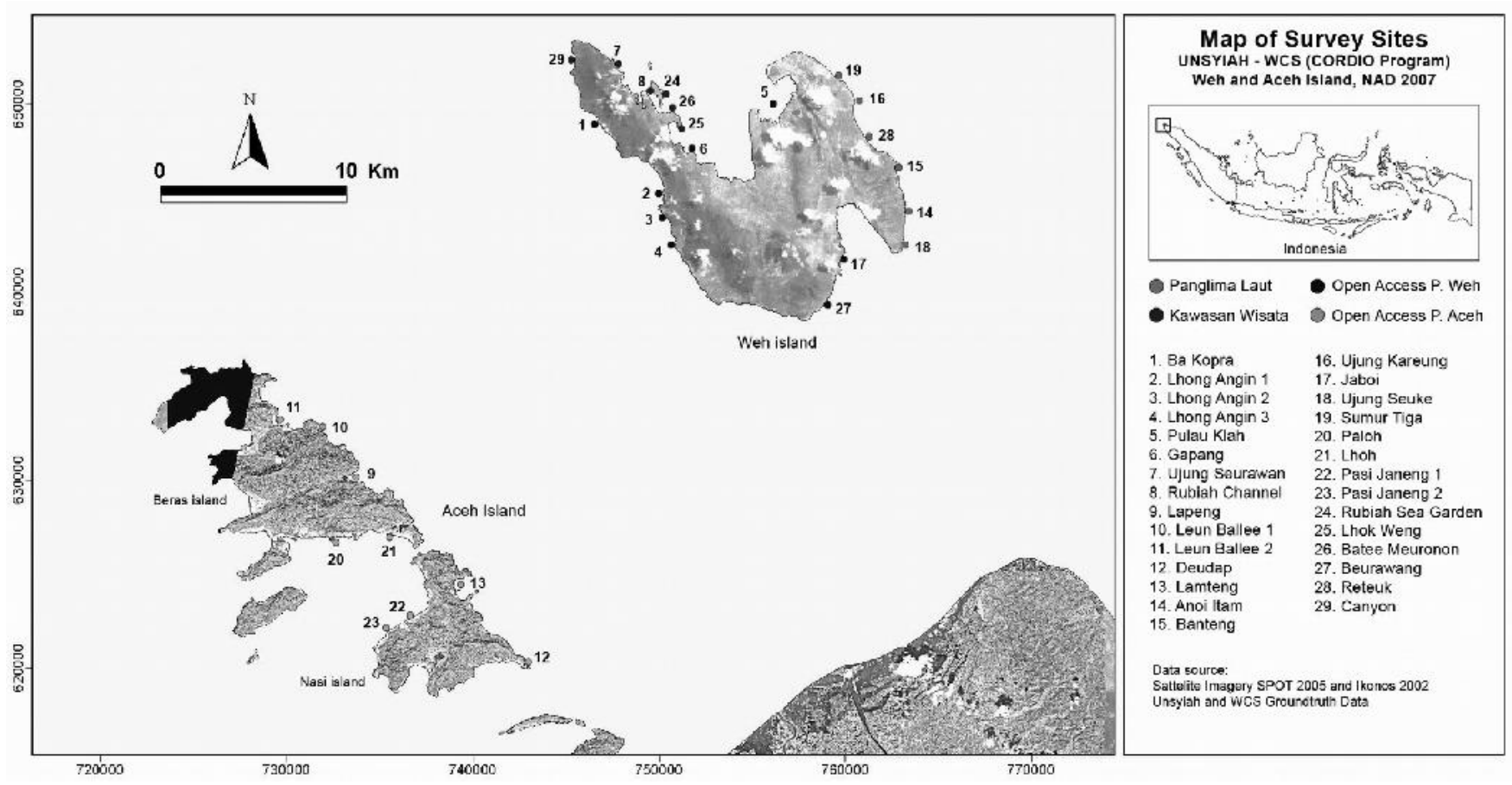

Figure 1. Map showing of survey sites at northern Acehnese coral reef ecosystem. 


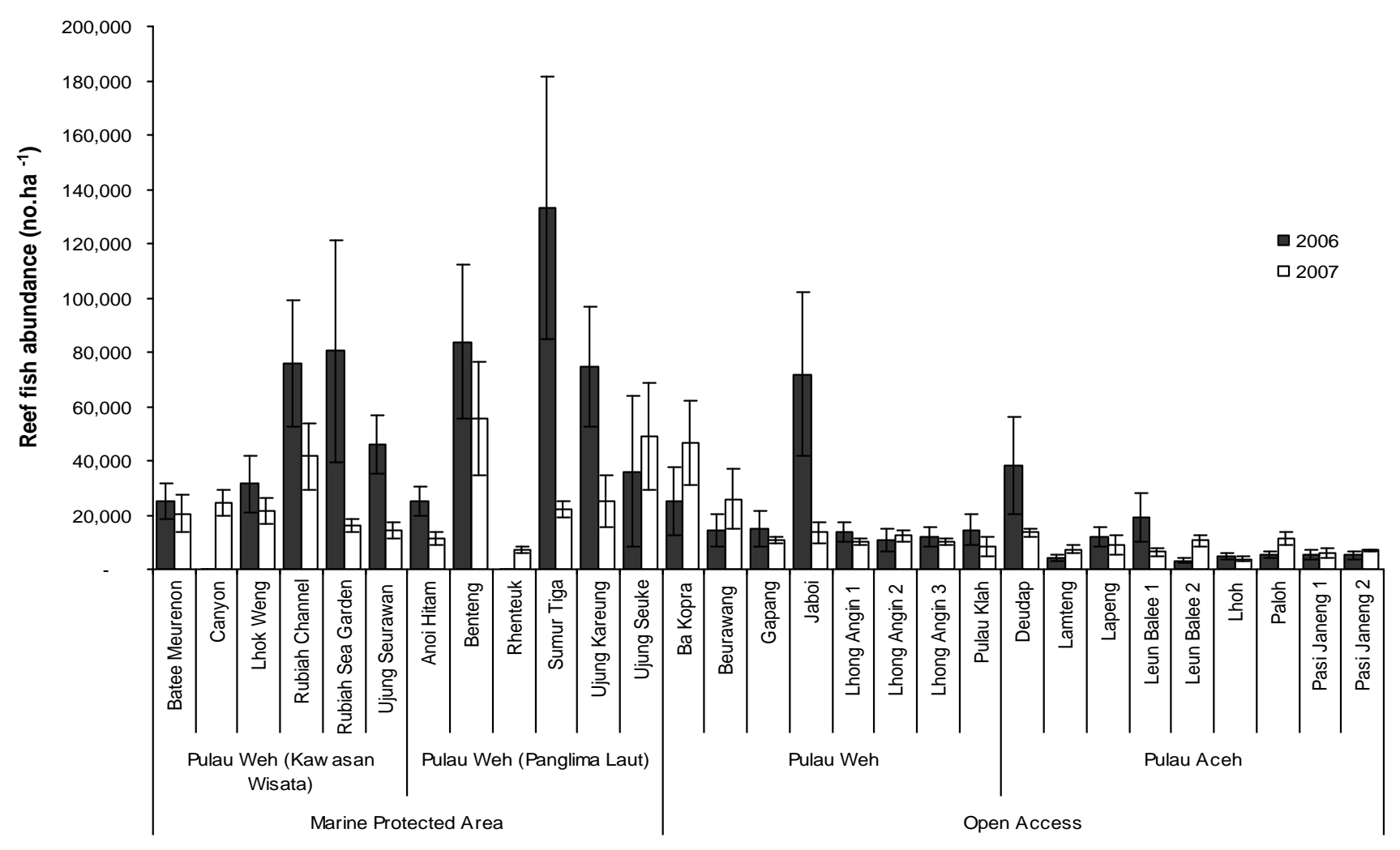

Figure 2. Mean abundance $\left( \pm\right.$ SE) $\left(\right.$ no.ha $\left.^{-1}\right)$ of reef fishes in 2006 and 2007 at each study site and in four management areas.

\section{RESULTS AND DISCUSSION}

In 2006, reef fish abundance was highest in Sumur Tiga $\left(133,050\right.$ no.ha $\left.^{-1}\right)$, while in 2007 it was highest at Benteng $\left(83,770\right.$ no.ha $\left.^{-1}\right)$ (Figure 2). Both sites were located within Panglima Laot management areas. Although the abundance of reef fishes was significantly affected by site (nested within management), the effects of management had a greater influence of fish abundance because of more fish within marine managed areas within Panglima Laot sites than open access sites $(F=2.586 ; P<0.05)$ the effects of management had a greater influence of fish abundance (i.e. Higher $F$ ratios; $F=37.671$; $P<0.005)$. Management controls that reduce pressure particularly on carnivorous and herbivorous reef fish species are urgently required to maintain reef diversity from having negative impacts on coral reefs.

The significant effect of time on fish abundance was due to a decrease in overall fish numbers from $2006\left(32,788\right.$ no.ha $\left.^{-1} \pm 4,313\right)$ to $2007\left(17,986 \mathrm{~kg} \mathrm{ha}^{-1}\right.$ $\pm 1,636)$. This decrease in fish abundance was due to lower numbers of Pomacentrids (Figure 3 ), which comprised much of the small size fishes $(5-10 \mathrm{~cm})$ that also decreased in numbers from 2006 to 2007.

The key finding of the 2007 survey was that reef fish abundance in marine managed areas was considerably better than in areas open to unregulated fishing activity on Weh Island. The low cover of live corals in the Aceh Islands indicates that the coral reefs of these islands have been heavily degraded by destructive fishing activities. These reefs also contain high numbers of macro-invertebrates, in particular sea urchin populations, that may be have been caused by the removal of predators by overfishing, and also from nutrient runoff from poorly located and managed agricultural development (Baird et al., 2005; Rudi et al., 2008). This result is supported by Wantiez et al. (1997) and Aswani et al. (2007) that species richness, density and biomass of reef fish on the protected reefs was higher and statistically significant compare with open access reef.

Pomacentrids were the most abundant reef fish present on these reefs and a major prey item for large carnivorous fishes, such as groupers, snappers, and jacks. The increasing numbers of carnivorous fish between 2006 and 2007 and increasing numbers of large size fishes $(20-25 \mathrm{~cm})$ which consisted mostly of groupers, snappers, and jacks (unpublished data) suggests that predation may be responsible for the overall decrease in fish abundance. Reduced fishing pressure following the tsunami in 2005 may have contributed to the increased numbers of large carnivorous fish.

In contrast, there was no significant different in reef fish biomass between 2006 and $2007(F=2.495$; $P>0.005$ ). Biomass of reef fishes in 2006 ranged from 118 to $2399 \mathrm{~kg} \cdot \mathrm{ha}^{-1}$. The highest was recorded at Sumur Tiga, and the lowest was at Pasi Janeng2. In 2007, biomass of reef fishes ranged from 149 to 1562 


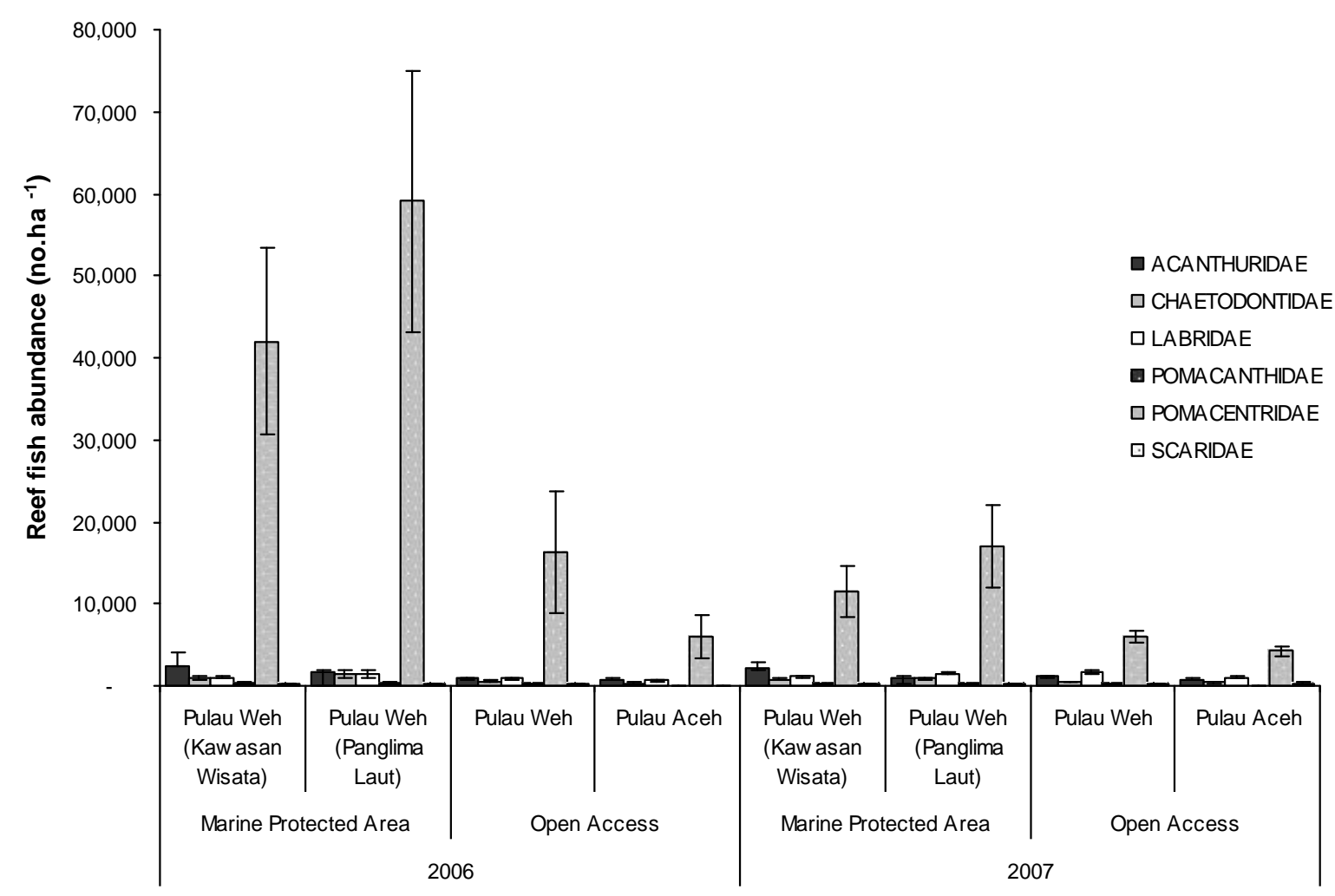

Figure 3. Mean $\left( \pm\right.$ SE) of abundance $\left(\right.$ no.ha $\left.{ }^{-1}\right)$ of reef fishes of 2006 and 2007 at each study site and type of management based on six major families that commonly found.

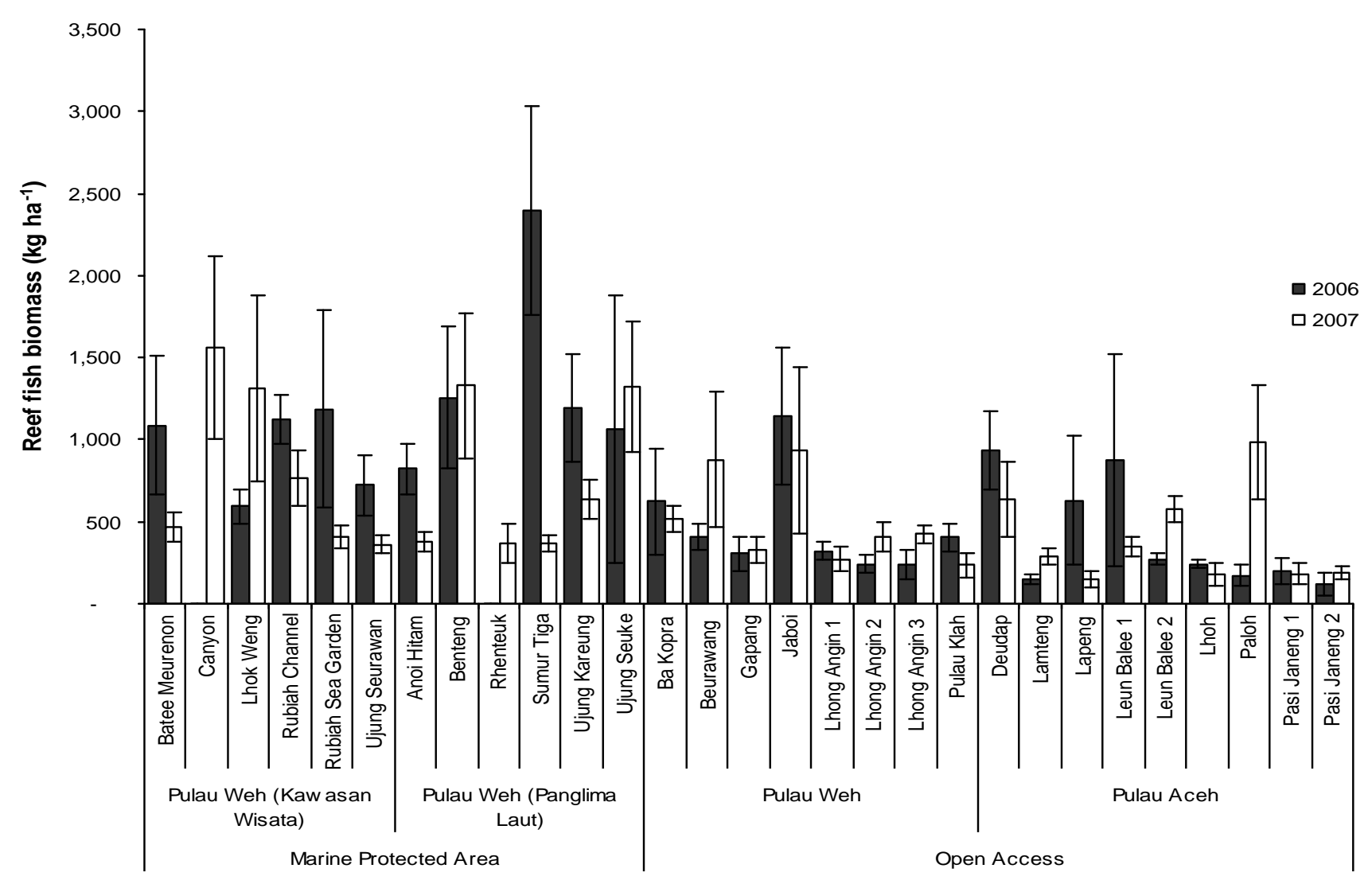

Figure 4. Mean ( \pm SE) of biomass $\left(\mathrm{kg} \cdot \mathrm{ha}^{-1}\right.$ ) reef fish of 2006 and 2007 at each site and four management areas. 


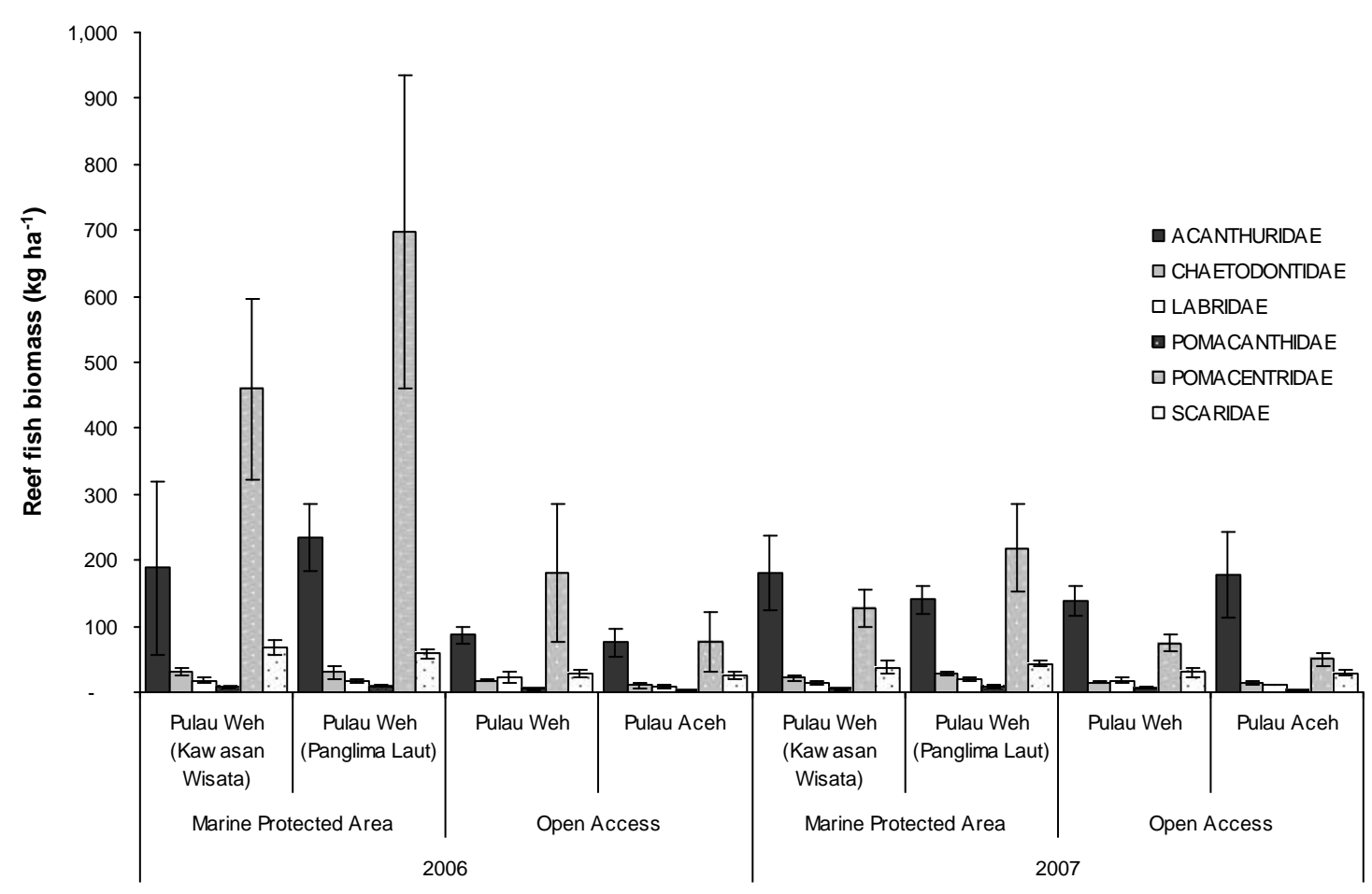

Figure 5. Mean biomass $\left( \pm\right.$ SE) $\left(\mathrm{kg} \cdot \mathrm{ha}^{-1}\right)$ of six major families reef fish in 2006 and 2007.

$\mathrm{kg} \cdot \mathrm{ha}^{-1}$, the highest was recorded at Canyon and the lowest at Lapeung (Figure 4). Sumur Tiga and Canyon were protected areas under the authority of Panglima Laot while Pasi Janeng 2 and Lapeng were open access areas in Aceh Islands. Reef fishes from the family Pomacentridae had the highest biomass of all sites in 2006 (Figure 5), but no change between 2006 and 2007 occurred as Acanthuridae comprised a large portion of the biomass in 2007, except within the areas under Panglima Laot where Pomacentridae was still dominant.

Overall the findings show that reef fishes abundance and biomass are highest within the areas where management controls are in place, suggesting that these controls should form a part of any future coral reef management strategies proposed for the region. Although the overall abundance of reef fish declined from 2006 to 2007, the cause of this is unknown. As it was occurring at many sites it is possible that non-anthropogenic factors such as migration, season or predation may be responsible. The decrease in Pomacentridae abundance and increase in the numbers of large fishes requires further investigation.

Population of carnivorous fish such as parrotfish (Family Scaridae) was low in all study sites. This indicated that northern Acehnese reef is lack of reef resilience both in managed and open access area. The consequent phase shift from coral to macroalgal dominated reefs would appear to support such predictions and even if coral recruitment does increase, the abundance of algae in this community may retard coral recovery. Parrotfish populations have been suffering severe declines worldwide and excavating species are particularly vulnerable (e.g. Bellwood et al., 2003; Aswani and Hamilton, 2004; Ferreira et al., 2005; Floeter et al., 2006; Sabetian and Foale, 2006). As these fihes represent one of the few groups responsible for opening up new areas of reef surface for colonization, their decline would promote a shift in the nature of grazing. The harvest of excavating parrotfish individuals not only reduces grazing activity but may change the dynamics of the epilithic algal matrix, the dominant substratum cover of most reef ecosystems. Higher herbivory in the fishery closures reduced the abundance and persistence of herbivore-susceptible erect algae and created space and appropriate substratum for recruiting corals (McClanahan, 2008). The Marine Protected Area adhered to many of the current paradigms regarding effective coral reef management; local anthropogenic stressors were virtually non-existent and effective enforcement of the MPA had led to healthy populations of herbivorous fishes (Jennings et al., 1996; Ledlie et al., 2007).

\section{CONCLUSIONS}

Overall the condition of reef fish abundance and biomass in marine managed areas was considerably better than in open access areas. These areas have been protected from blasting and cyanide fishing while Aceh Islands' reefs have been subjected to unregulated fishing and destructive fishing. A reduction in destructive fishing activities was indicated 
by an increase in the number of carnivorous fish from 2006 to 2007, such as groupers, snappers, and jacks which are target species for local fisheries. Higher numbers and abundance of reef fish in marine managed areas, such as Panglima Laot in Sabang, could be considered for further conservation purpose of marine resources, especially in Nanggroe Aceh Darussalam Province. Further studies and monitoring are required to examine if recovery of Aceh Island reefs continues and compare these trends with nearby reefs where existing management controls on fisheries also require support and strengthening.

\section{ACKNOWLEDGEMENTS}

Authors would like to thanks IUCN-CORDIO (Coastal Oceans Research and Development-Indian Ocean) for funding. Thanks also to Director of Marine Science Center of Syiah Kuala University; Dr. Hansa Chansang from Phuket Marine Biological Centre (PMBC) Thailand; and for U-Dive Shop at Sabang, Aceh.

\section{REFERENCES}

Allen, G.R., and M. Adrim. 2003. Coral reef fish of Indonesia. Zoological Studies 42: 1-72.

Ardiwijaya, R.L., T. Kartawijaya, Y. Herdiana, and F. Setiawan. 2007. The Coral Reefs of Northern Aceh: an Ecological Survey of Aceh and Weh Islands, April 2006. Bogor: Wildlife Conservation Society-Marine Program Indonesia.

Aswani, S., and R.J. Hamilton. 2004. Integrating indigenous ecological knowledge and customary sea tenure with marine and social science for conservation of bumphead parrotfish (Bolbometopon muricatum) in the Roviana Lagoon, Solomon Islands. Environmental Conservation 31: 69-83.

Aswani, S., S. Albert, A. Sabetian, and T. Furusawa. 2007. Customary management as precautionary and adaptive principles for protecting coral reefs in Oceania. Coral Reefs 26:1009-1021

Baird, A.H., S.J. Campbell, A.W. Anggoro, R.L. Ardiwijaya, N. Fadli, Y. Herdiana, T. Kartawijaya, D. Mahyiddin, A. Mukminin, S.T. Pardede, M.S. Pratchett, E. Rudi, and A.M. Siregar. 2005. Acehnese reefs in the wake of the Asian Tsunami. Current Biology 16:1926-1930

Bellwood, D.R., A.S. Hoey, and J.H. Choat. 2003. Limited functional redundancy in high diversity systems: resilience and ecosystem function on coral reefs. Ecological Letter 6: 281285.

Brown, B.E. 2005. The fate of coral reefs in the Andaman Sea, eastern Indian Ocean following the Sumatran earthquake and tsunami, 26 December 2004. The Geographical Journal 171: 372-374

Campbell, S.J., R.L. Ardiwijaya, S.T. Pardede, Y. Herdiana, A. Mukminin, T. Kartawijaya, A.W. Anggoro, A.M. Siregar, N. Fadli, and A.H. Baird. 2005a. Impacts of the Tsunami on Coral Reefs in the Northern Aceh Region-A report to USAID Coastal Resource Management Project II. Bogor: WCS-Marine Program, Indonesia.

Campbell, S.J., M.S. Pratchett, A.W. Anggoro, R.L. Ardiwijaya, N. Fadli, Y. Herdiana, T. Kartawijaya, D. Mahyiddin, A. Mukminin, S.T. Pardede, E. Rudi, A.M. Siregar, and A.H. Baird. 2005b. Disturbance to coral reef in Aceh, Northern Sumatra: impacts of the Sumatra-Andaman tsunami and pre-tsunami degradation. Atoll Research Bulletin 544: 55-78.

English, S., C. Wilkinson, and V. Baker. 1997. Survey Manual for Tropical Marine Resources. Townsville: Australian Institute of Marine Science.

Ferreira, C.E.L., J.L. Gasparini, A. Carvalho-Filho, and S.R. Floeter. 2005. A recently extinct parrotfish species from Brazil. Coral Reefs 24:128-134.

Floeter, S.R., B.S. Halpern, and C.E.L. Ferreira. 2006. Effects of fishing and protection on Brazilian reef fishes. Biological Conservation 128: 391-402.

Hill, J., and C. Wilkinson. 2004. Methods for Ecological Monitoring of Coral Reefs. Townsville: Australian Institute of Marine Science.

Jennings, S., S.S. Marshall, and N.V.C. Polunin. 1996. Seychelles' marine protected areas: comparative structure and status of reef fish communities. Biological Conservation 75: 201-209.

Ledlie, M.H., N.A.J. Graham, J.C. Bythell, S.K. Wilson, S. Jennings, N.V.C. Polunin, and J. Hardcastle. 2007. Phase shifts and the role of herbivory in the resilience of coral reefs. Coral Reefs 26: 641-653

McClanahan, T.R. 2008. Response of the coral reef benthos and herbivory to fishery closure management and the 1998 ENSO disturbance. Oecologia 155: 169-177

Randall, J.E. 1998. Zoogeography of shore fishes of the IndoPacific region. Zoological Studies 37: 227-268.

Rudi, E. 2005. Kondisi terumbu karang di perairan Sabang Nanggroe Aceh Darussalam setelah tsunami. IImu Kelautan 10: $50-60$

Rudi, E., S.A. Elrahimi, S. Irawan, R.A. Valentino, Surikawati, Yulizar, Munandar, T. Kartawijaya, Y. Herdiana, F. Setiawan, S. Rizal, S.T. Pardede, and S.J. Campbell. 2008. Post Tsunami Status of Coral Reef and Fish in Northern Aceh, CORDIO Report. Banda Aceh: Unsyiah-IUCN /CORDIO-WCS.

Sabetian, A., and S. Foale. 2006. Evolution for artisanal fisher: case studies from Solomon Islands and Papua New Guinea. SPC Traditional Marine Resources Management Knowledge Information Bulletin 20: 3-8.

Wantiez, L., P. Thollot, and M. Kulbicki. 1997. Effects of marine reserves on coral reef fish communities from five islands in New Caledonia. Coral Reefs 16: 215-224. 